\title{
ArcheoSciences
}

Revue d'archéométrie

41-2 | 2017

Varia

\section{Santo Domingo's Hispanic convent, Panama. A new appraisal from 3D resistivity survey}

Le couvent Hispanique de Santo Domingo, Panama. Une nouvelle évaluation à partir d'une prospection électrique 3D

Alexis Mojica, Graciela Arosemena Díaz, Javier Grajales and Félix Durán

\section{OpenEdition}

\section{Journals}

\section{Electronic version}

URL: https://journals.openedition.org/archeosciences/5018

DOI: 10.4000/archeosciences. 5018

ISBN: 978-2-7535-7393-2

ISSN: 2104-3728

Publisher

Presses universitaires de Rennes

\section{Printed version}

Date of publication: 8 December 2017

Number of pages: 85-94

ISBN: 978-2-7535-7391-8

ISSN: 1960-1360

\section{Electronic reference}

Alexis Mojica, Graciela Arosemena Díaz, Javier Grajales and Félix Durán, "Santo Domingo's Hispanic convent, Panama. A new appraisal from 3D resistivity survey", ArcheoSciences [Online], 41-2| 2017, Online since 08 December 2019, connection on 28 January 2022. URL: http:// 


\title{
Santo Domingo's Hispanic Convent, Panama. A New Appraisal from 3D Resistivity Survey
}

\author{
Le couvent hispanique de Santo Domingo, Panama. \\ Une nouvelle évaluation à partir d'une prospection électrique $3 D$
}

\author{
Alexis Mojica ${ }^{a}$, Graciela Arosemena Díaz ${ }^{b}$, \\ Javier Grajales ${ }^{c}$ and Félix Durán ${ }^{\mathrm{d}}$
}

\begin{abstract}
In 2012, a geophysical survey was conducted inside the open space of a Hispanic Dominican convent in Panama (Central America); its ruins form part of the Panamá Viejo Historical Monument Complex, which was declared a UNESCO World Heritage site in 2003. The geophysical survey consisted of measuring the apparent electrical resistivity values along 24 parallel profiles inside the convent; the aim of this approach was focused on generating $3 \mathrm{D}$ electrical resistivity tomography in order to detect buried structures that could be associated with a possible cloister in this area of the convent. This dataset was inverted using a smooth inversion algorithm and shows important electrical anomalies on three horizontal maps at depths of $0.29,0.90$ and $1.60 \mathrm{~m}$. The main electrical anomalies presented linear and isolated geometries that, in accordance with the archaeological excavations conducted at the site, are linked to a series of buried cultural features associated with the convent's cloister, such as perimeter walls, pillar footings and bases made of stone as supports for the gallery of a second floor. This study was also able to identify other archaeological features that could be linked to the initial stages of the construction of this important building.
\end{abstract}

Résumé : En 2012, une prospection géophysique a été faite sur l'espace libre d'un couvent hispanique dominicain au Panama (Amérique centrale). Ses ruines font partie du Complexe Monumental Historique de Panamá Viejo qui a été classé au Patrimoine Mondial de l'Unesco en 2003. L'étude géophysique a consisté à mesurer les valeurs de la résistivité électrique apparente le long de 24 profils parallèles à l'intérieur du couvent. Cette approche par tomographie de résistivité électrique 3D avait pour but de détecter les structures enterrées qui pourraient être associées à un cloître dans cette partie du couvent. Les données ont été inversées à l'aide d'un algorithme d'inversion lisse. Les variations de la résistivité sont importantes, elles sont présentées pour 3 sections horizontales aux profondeurs de 0,29, 0,90 et 1,60 m. Les principales structures présentent des périphériques linéaires bien identifiables qui, conformément aux fouilles archéologiques menées sur le site, peuvent être associées au cloître du couvent: murs périfériques, pieds et bases en pierre supports de la galerie d'un deuxième étage. Cette étude a également permis d'identifier d'autres caractéristiques archéologiques qui pourraient être liées aux états antérieurs de la construction de cet important bâtiment.

Keywords: comparison with excavations, electrical anomaly, electrical resistivity tomography, Panamá Viejo, Santo Domingo convent, 3D inversion.

Mots clés : comparaison avec les fouilles archéologiques, Anomalie électrique, couvent de Santo Domingo, inversion 3D, Panamá Viejo, tomographie de résistivite électrique.

${ }^{a}$ Laboratorio de Investigación en Ingeniería y Ciencias Aplicadas, Centro Experimental de Ingeniería, Universidad Tecnológica de Panamá, 0819-07289 EL DORADO, Panama and Sistema Nacional de Investigación, SENACYT, Panama. (alexis.mojica@utp.ac.pa)

${ }^{b}$ Facultad de Arquitectura, Universidad de Panamá, Estafeta Universitaria, Apartado 3366 Panamá 4, Panama.

c Facultad de Ingeniería Civil, Universidad Tecnológica de Panamá, 0819-07289 EL DORADO, Panama.

' Patronato Panamá Viejo, 0823-05096, Panama. 


\section{INTRODUCTION}

In Archaeology, the use of geophysical techniques is increasingly more common in preliminary delimitation studies; this is because of their non-destructive nature and the short data collection periods at sites with a large surface area. This means a significant reduction in the costs of such studies. The lateral extent and depth of buried archaeological features can be detected, electrical surveying being one of the most widely used in archaeology as such features tend to present different electrical properties from those in the surrounding environment. However, it is important to note that the effectiveness of the method is dependent on the technological advances of data collection devices (multielectrode systems) and the development of computational programs for inverse problem solving in two or three dimensions. The application of such methods in the Americas has played an important role in the detection and parameterization of Pre-Columbian and Hispanic archaeological features (Osella et al., 2005; Wake et al., 2012; Minelli et al., 2012).

The aim of this study was to perform 3D electrical resistivity tomography in an open space located inside the ruins of Santo Domingo Convent (Panamá Viejo Historical Monument Complex) in order to detect possible archaeological structures that could be linked to the characteristic structures of a cloister and additional features linked to the origins of the construction of this building. Based on this 3D (three-dimensional) tomography geophysical survey, horizontal sections were drafted to provide a better interpretation of the areas of high electrical resistivity, thereby permitting an understanding of the spatial and temporal organization of the occupation of the convent during the period of Spanish colonization of the American continent.

\section{GeOgraphical aNd GEOlOgiCAL SETTING}

The ancient Hispanic city of Panamá Viejo was the first and most important European settlement on the American Pacific coast during the Spanish conquest and colonization. Its ruins are located close to the modern city of Panama, on the widest part of the Isthmus as shown in Figure 1a, and Santo Domingo Convent is located in the central sector of the archaeological site (Figure 1b).

The site stands on three geologic formations: the Panamá Formation (volcanic and marine phases) and Las Lajas Formation. The volcanic phase is the most predominant, while Las Lajas Formation, located in the northeastern vicinity of the area of interest (Figure 1c), has a lesser extent.

\section{Historical CONTEXT}

The Santo Domingo Convent in Panama was initially founded in 1519 in the city of Nombre de Dios on the Caribbean coast and was later transferred to Panama City, where it started operating in 1571. After that, the convent underwent numerous transformations through a construction process using non-perishable materials, until it was abandoned along with the rest of the city as a consequence of the attack of the city by the pirate Henry Morgan in 1671.

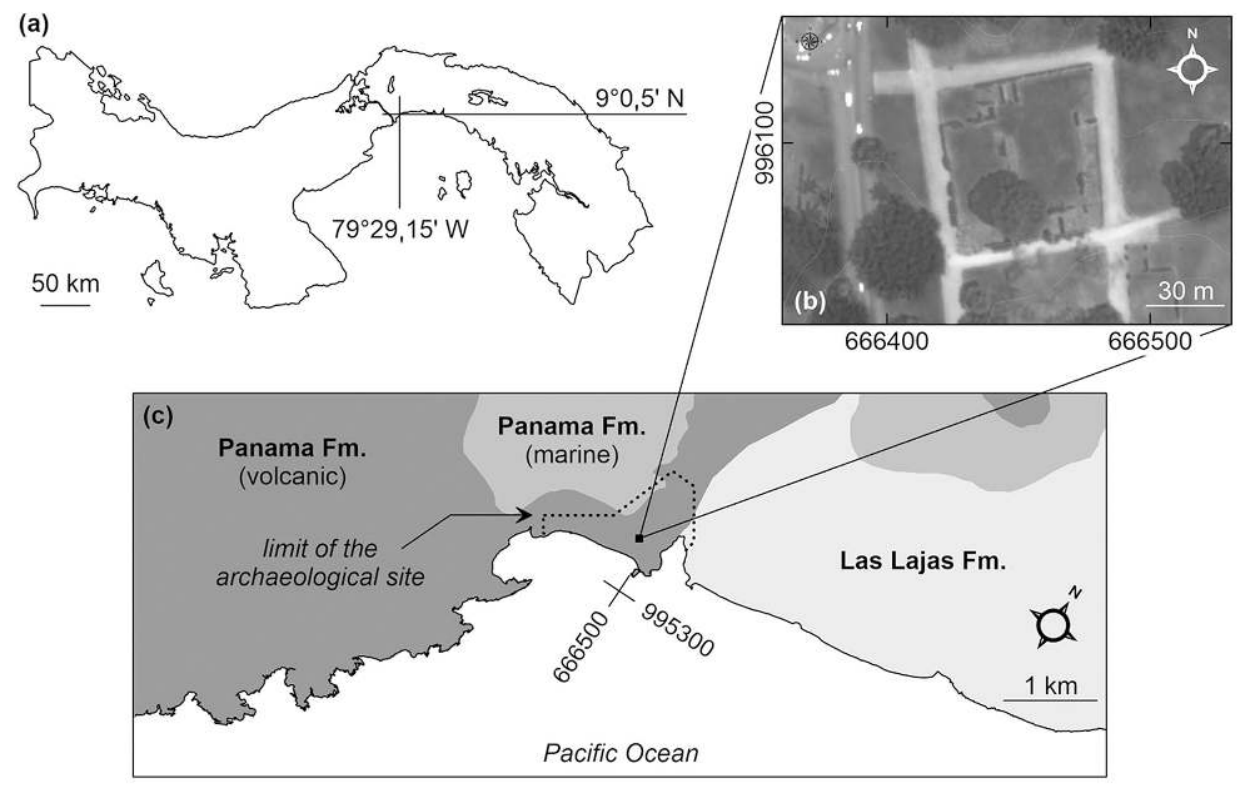

Figure 1: a) Geographic location of the area of interest on the Isthmus of Panama, b) overhead view of Santo Domingo Convent and c) geological description of the area and surroundings (Stewart et al., 1980).

Figure 1 : a) Localisation géographique du site étudié sur l'isthme de Panama, b) vue aérienne du Couvent de Santo Domingo et c) description géologique de la zone et de ses environs (Stewart et al., 1980). 
The characteristics of the convent's initial phase are described in a report to the King by Doctor Alonso Criado de Castilla, dated on April 30, 1577 which mentions the use of wood and tiles to build the convent, the use of cane to mark the boundaries of the property and the existence of an adjacent house that was used as a church.

In terms of construction, that wooden house can be interpreted on the basis of the description by Bishop Juan de Fonseca of the technique used for wooden homes in the old city of Panama, which also describes the use of wood with stone bases. From this information, we can infer that although historical records indicate that the convent was made of wood in its initial phase, its foundations would have been laid with stone materials in accordance with building traditions in the city (Mena García, 1992).

The convent maintained these initial characteristics until early seventeenth century (1610 description). Although there is no direct historical reference to the exact date when building with masonry, stones and bricks began, this could have occurred between 1610 and 1614 (Arosemena \& Durán, 2014) because the Royal Chapter of December 15, 1614, addressed to the Provincial Prior of Peru mentions the application for a tabernacle and an altarpiece for the new church in 1614.

From that moment, the convent continued to be built using masonry over various periods of the seventeenth century, as evidenced by several wall joints (Linero and Muñíz, 2013). Finally, the convent was abandoned in 1671, following the pirate Morgan's attack on Panama City. Later, during more than 300 years of abandon, the convent's structures and walls have deteriorated. The ruins are still visible today, in testimony to the building's past before being abandoned in 1671 (Figure 2).

\section{The convent in colonial cartography}

The known cartographic references to the old city of Panama are two maps produced at two historic moments. The first was produced in 1586 by Bautista Antonelli, and the second by Cristóbal de Roda in 1609. Both maps show the location of Santo Domingo Convent, and a description from 1607 confirms the existence of Santo Domingo Convent and a street of the same name to the west. The description also reveals that the street to the north of the convent was called Calle de la Puentezuela. No name is known for the streets to the east and south. Regarding the characteristics of the convent, there are differences between the representations on the maps by Antonelli and Roda. The central part of Antonelli's map (Figure 3) shows a different layout of the convent from that of the present-day

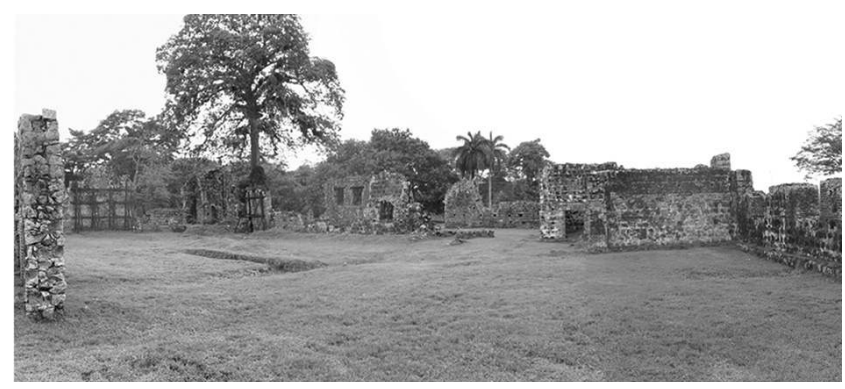

Figure 2: Panoramic interior view of Santo Domingo Convent, Panamá Viejo Archaeological Site. Photo by G. Arosemena. Figure 2: Vue panoramique intérieure du Couvent de Santo Domingo, site archéologique de Panamá Viejo. Photo par G. Arosemena.

ruins, which not only features an irregular perimeter, but also fewer signs of occupation.

The Calle de Santo Domingo, to the west of the convent, was already laid out and the convent's northeastern boundary was presumably well defined; the street running parallel to Santo Domingo also seems to have been laid out, and so the eastern boundary of the convent was also defined. However, both Calle de la Puentezuela, on the northern boundary of the convent, and the street to the south, were undefined in 1586; this probably reflects how the block on which the convent stood was not well-delimited.

This map of the convent by Bautista Antonelli probably represents the primitive Santo Domingo Convent mentio-

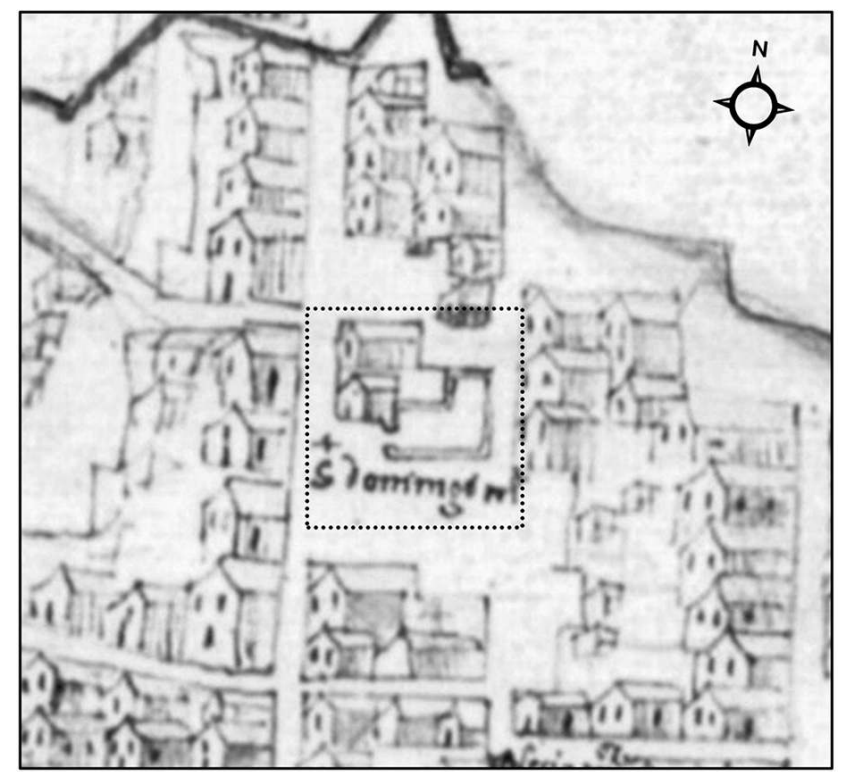

Figure 3: Santo Domingo Convent in 1586, from a map of Panama produced by Bautista Antonelli.

Figure 3: Couvent de Santo Domingo en 1586, carte de Panama par Bautista Antonelli. 
ned in the chronicles as the wooden house. By 1609, the map of Panama City produced by Cristóbal de Roda, despite not detailing the convent buildings, shows substantial changes to the Santo Domingo block.

It is shown in a more defined, regular and broad manner, with a similar perimeter to that seen in the block of the present-day ruin; the boundaries of the convent block had thus probably been defined by this date (1609), as shown by the defined routes of the streets around it. However, according to the 1610 description, the convent was still known as a wooden house. This presumably means that despite the consolidation of the block, no masonry work had yet been done, and the convent probably had the same constructed outline as that shown on the 1586 map. When the convent was abandoned in 1671, the block probably had the same boundaries as those observed in the present-day ruins, which had probably been defined as of 1609 .

By comparing the block shown in Antonelli's map with the map of the block of the present-day ruin (Figure 4), not only is an irregular perimeter noted, but it can also be clearly seen that the northeast section of the convent in Antonelli's map was unbuilt, and in that sector, the northern limit of the convent building would have been located in the middle of the current convent.

This northern space was presumably added to the convent block during its consolidation process, but it does not seem to have been built upon, which is why it is hypothesized that the convent was not completed before Morgan's arrival (Arosemena and Durán, 2014).

\section{Description of the cloister at Santo Domingo Convent}

Most of the walls and wall foundations of the convent site, which were abandoned in 1671 and are now in ruins, are of legible masonry. This means that the architectural layout is still comprehensible. In general, colonial convent sites like Santo Domingo followed the medieval tradition of Benedictine convents, which defined the characteristics of the architectural typology in Europe. And because the

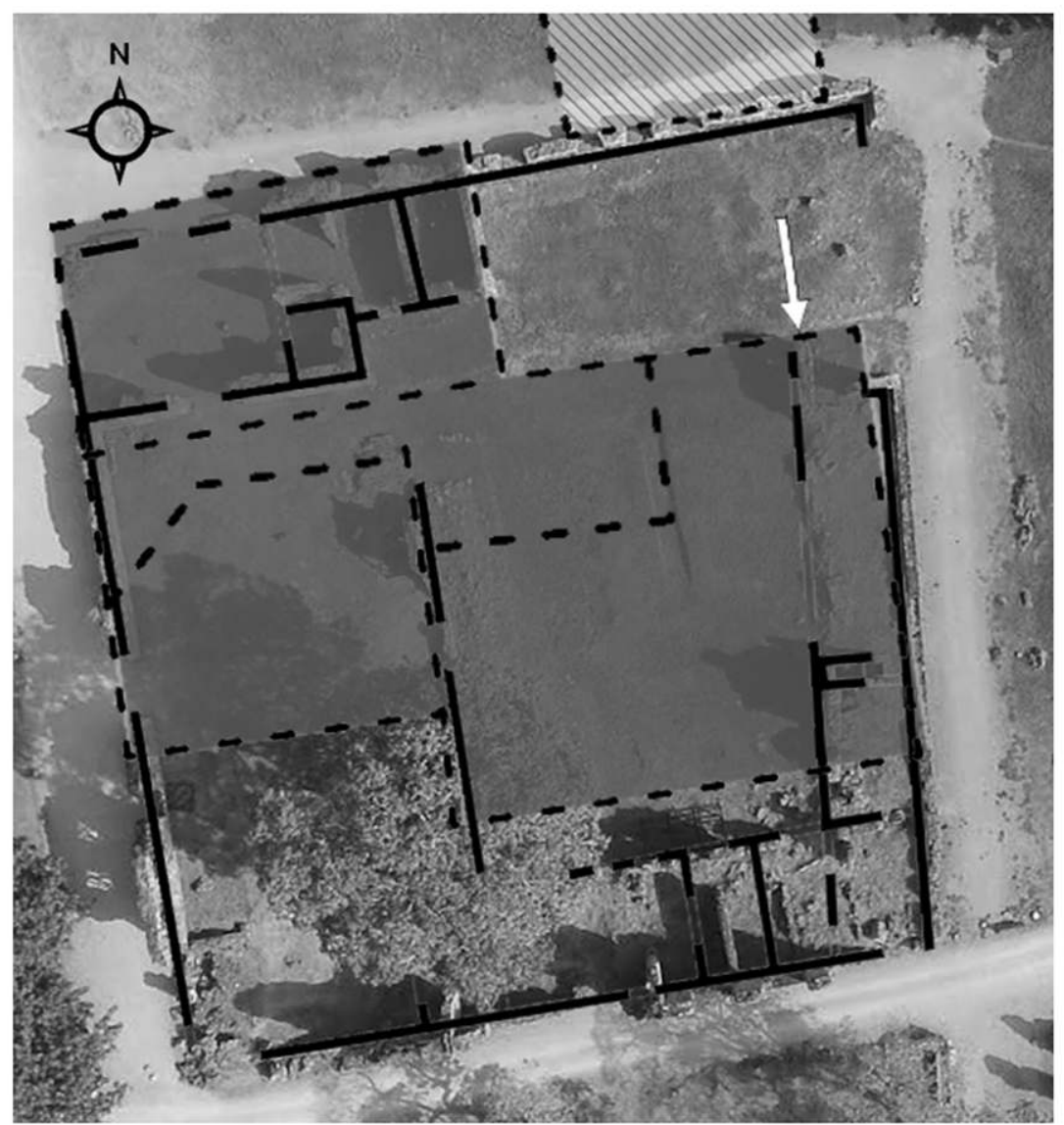

Probable trace of the convent in 1586 according to the map of Antonelli.

Trace of a probable house linked to the still unbound block Nord of the convent of Santo Domingo in 1586.
Figure 4: Comparison of the outline of the convent in its wooden phase, according to Antonelli's map (dashed lines), with the map of the convent at its most advanced stage, corresponding to the present-day ruins. A white arrow shows the northern boundary of the convent. Source: G. Arosemena.

Figure 4: Comparaison du contour du couvent dans sa phase de bois, d'après la carte d'Antonelli (lignes pointillées), avec la carte du couvent à son stade le plus avancé, correspondant aux ruines actuelles. Une flèche blanche montre la limite nord du couvent. Source: G. Arosemena. 
religious functions and activities, including evangelical and educational functions, of convent buildings in the Americas remained similar to those of convents in Spain and the rest of Europe, they maintained the same inherent types of convent buildings and spaces: the cloister, consisting of a patio surrounded by four arcades, the Church and the convent outbuildings.

Following this pattern, in the space corresponding to the cloister, neither the galleries nor the elements constituting its porticos, i.e., the pillars, are visible in the present-day ruins. However, it is possible to make out the open space of the patio, which is contained within the visible walls of the nave of the Church and the outbuildings to the south and east.

\section{SURVEY METHODOLOGY}

\section{Delimitation of the survey area}

The geological characteristics of the Panamá Viejo Historical Monument Complex permitted electrical surveying in the space occupied by Santo Domingo Convent. In a $923 \mathrm{~m}^{2}$ polygon, a total of 24 parallel electrical profiles were set from southeast to northwest, with a $1 \mathrm{~m}$ separation between them. The definition of this polygon was determined by the presence of obstacles on the edges of the survey area (accumulation of rubble, remains of fallen walls and trees). In the aforementioned polygon, the first 5 profiles were established in the western part of the convent area, the following 17 profiles in the central zone and the last 2 profiles in the eastern area, with lengths of 25,47 and $23 \mathrm{~m}$, respectively. Figure 5 shows a map of the area of the convent and Santo Domingo Church, along with the boundaries of the archaeological interventions, the surveyed area and the positions of the 24 profiles.

\section{Geometric and acquisition parameters}

In each set profile, the apparent electrical resistivity values were obtained using a multielectrode system consisting of a Syscal R1 switch 48 resistivity meter (by Iris Instruments) and two multicable devices with 24 outputs each.

The system permits a linear arrangement with a maximum total of 48 electrodes, with an electrode separation of no more than $5 \mathrm{~m}$. Prior to surveying, two types of parameters were configured: (i) geometric - the number of electrodes (which varies depending on profile length) and the separation between them, which is constant $(1 \mathrm{~m}$ for this study), the electrode configuration (dipole-dipole) and the total number of depth levels $(n=7)$; and (ii) acquisition levels - the maximum permitted standard deviation value of the field data ( $1 \%$ for this study), minimum and maximum number of stacks per measurement ( 3 and 6 ), the time cycle $(500 \mathrm{~ms})$ and the type of signal. The dipole-dipole electrode configuration typically offers high resolution, but it is highly sensitive to geological noise and shallow exploration depths (Barker, 2001). The acquisition parameters chosen for this study guarantee good quality data.

\section{Inversion model}

The 5950 apparent electrical resistivity values collected for the 24 profiles were processed using the EarthImager 3D program by AGI Advanced; this program constructs an initial resistivity model based on the apparent electrical resistivity values and then iterates direct 3D modeling in order to predict the synthetic values of apparent electrical resistivity in accordance to the experimental data. In order to resolve the direct model, the finite difference method is used, in which the medium is discretized and the partial differential eauation is solved:

$$
\nabla \cdot[\sigma(x, y, z) \nabla \Phi(x, y, z)]=i \delta\left(r-r_{S}\right)
$$

In this equation $\Phi$ corresponds to the scalar electric potential, $\mathrm{i}$ is the intensity of the electric current, $\sigma$ is the distribution of electrical conductivity at a running point $\mathrm{r}$, $\left(r=\sqrt{x^{2}+y^{2}+z^{2}}\right) \delta$ is Dirac's Delta function and $\mathrm{r}_{S}$ is the location of the source (Dey \& Morrison, 1979). This study used the smoothest inversion or Occam method (Constable et al., 1987; de Groot-Hedlin \& Constable, 1990) which seeks the best possible smoothing method whose response fits the data measured using a Chi-square cost function. Once the inverse problem has been solved, calculated electrical resistivity data corresponding to a certain depth are interpolated and presented in a horizontal map for clear display of the results.

\section{Archaeological excavations}

Following the geophysical survey and based on the results obtained from it, a visual survey was conducted in the area of interest; then a total of 7 archaeological interventions were performed, from which 5 were located inside the surveyed area. A total of 2 trenches and one sounding were specifically selected using consecutive stripping of stratigraphic layers as the archaeological survey method. These archaeological excavations were directed by Mirta Linero from the Patronato Panamá Viejo.

The first trench (TR1) was defined in an east-west direction, with a width of $2 \mathrm{~m}$ and length of $28 \mathrm{~m}$; while the 


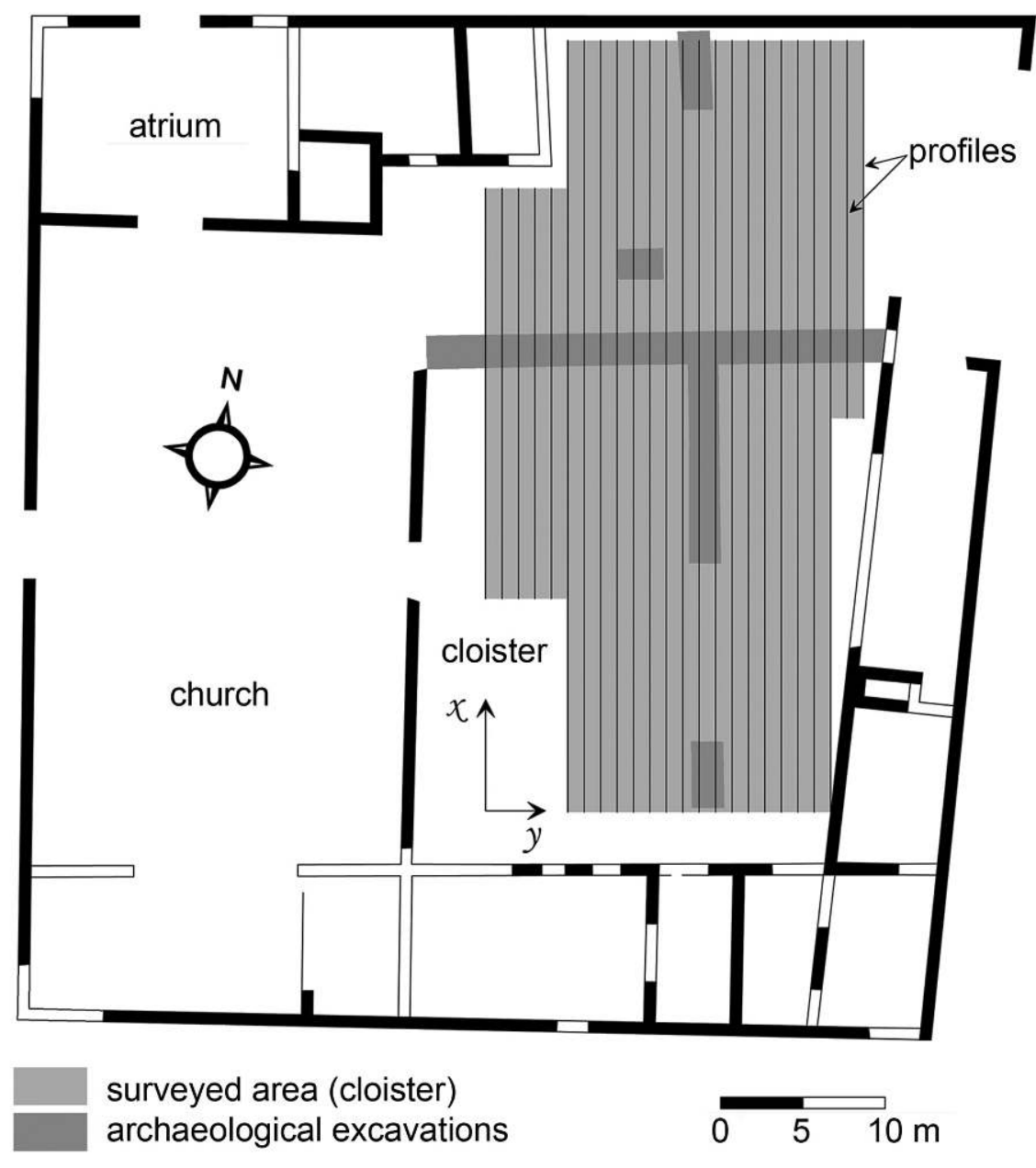

Figure 5: Map of Santo Domingo Church and convent, distribution of the 24 profiles for $3 \mathrm{D}$ electrical resistivity tomography and areas of the archaeological excavations performed at this site.

Figure 5: Carte de l'église et du couvent de Santo Domingo, position des 24 profils de la tomographie de résistivité électrique $3 D$ (en gris clair) et délimitations des fouilles archéologiques réalisées sur ce site (en gris foncé). second trench (TR2) was defined perpendicularly to the previous trench (in a north-south direction). However, because of the length of that trench, three sectors of varying dimensions of the same were explored (north, center and south), represented by notations TR2-north $(4.8 \times 2.0) \mathrm{m}^{2}$, TR2center and TR2-south $(4.0 \times 2.0) \mathrm{m}^{2}$. Meanwhile, in the northwest sector of the convent, an archaeological sounding was performed with notation $S 1$ of $(2.0 \times 3.0) \mathrm{m}^{2}$. Figure 5 shows the layout of these archaeological interventions superimposed over the geophysical surveyed zone.

\section{RESULTS AND DISCUSSION}

\section{D Electrical resistivity tomography}

The quality of the field data can be classed as reliable due to the low percentage error obtained during the acquisition process; on the other hand, the inverse problem was resolved after a total of 3 iterations, obtaining a low RMS error $(6.0 \%)$. From this analysis, three horizontal maps could be extracted at different depths $(z=0,29 \mathrm{~m}, 0,90 \mathrm{~m}$ and $1,60 \mathrm{~m}$ ) as shown in Figure 6. This representation can be used to reveal the lateral extension of the electrical anomalies associated with possible buried archaeological structures.

In the first horizontal map $(z=0,29 \mathrm{~m})$, a long electrical anomaly in red was identified with intermediate calculated electrical resistivity values in parallel to the North wall of the convent, which contains two isolated anomalies (brown tonality) that as a whole present a range of calculated electrical resistivity values varying between 23.4 and $50.0 \Omega$.m, this same alignment appears in the second horizontal map $(z=0,90 \mathrm{~m})$, but with a greater spatial extent of the isolated anomalies. In the third horizontal map $(z=1,60 \mathrm{~m})$, this series becomes weaker, conserving the position of the isolated anomalies (in red tonality), with the remainder represented in yellow tonality, with calculated electrical resistivity values varying between 7.5 and $23.4 \Omega$.m. 


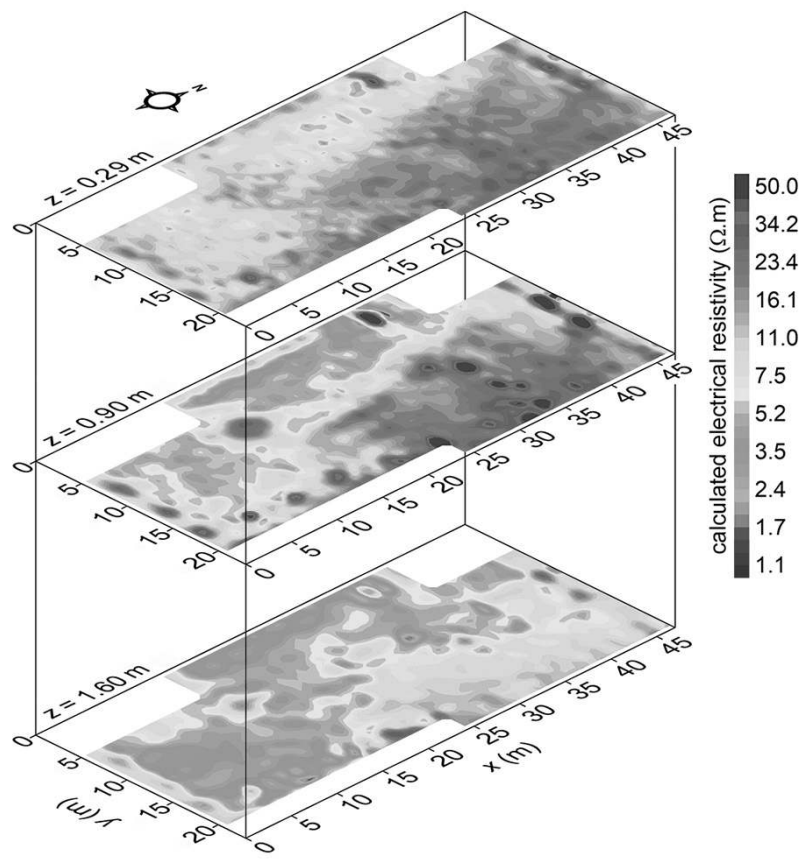

Figure 6: (See colour plate XX) Presentation of the horizontal maps at different depths $(z)$, as a result of the $3 \mathrm{D}$ inversion of the apparent electrical resistivity data obtained inside Santo Domingo Convent.

Figure 6: (Voir planche couleur XX) Présentation des sections horizontales à différentes profondeurs (z), résultant de l'inversion $3 D$ des données de résistivité électrique apparentes obtenues dans le Couvent de Santo Domingo.

In the Southern part of the convent, 3D electrical surveying was able to reveal the existence of a series of isolated electrical anomalies (in red and brown tonalities) in the first and second horizontal maps, with calculated electrical resistivity values varying between 23.4 and $50.0 \Omega$.m. In the upper map, it was possible to weakly identify a total of three (red) electrical anomalies, with a range of calculated electrical resistivity values that varied between 23.5 and 34.2 $\Omega . \mathrm{m}$. In the second map, these isolated electrical anomalies were more defined and intense, reaching calculated electrical resistivity values of up to $50.0 \Omega$.m. In the third horizontal map, these isolated electrical anomalies are rather weak. However, one (yellow and orange) anomaly could be clearly identified in parallel to the South wall of the convent, with calculated electrical resistivity values ranging between 7.5 and $16.1 \Omega . \mathrm{m}$.

The results also show a third linear electrical anomaly parallel to the west wall of the convent that is only visible in the first and second maps. In the first, this anomaly is not completely clear, but it is possible to identify a series of (red) anomalies whose range of calculated electrical resistivity values varies between 23.4 and $34.2 \Omega$.m. At a greater depth, the anomaly becomes clearer in the second map (in yellow and orange), with a wider range of calculated electrical resistivity values (7.5-23.4 $\Omega$.m). This electrical anomaly could not be identified in the third map.

In the east sector of the surveyed area, a series of isolated anomalies could be identified that are more pronounced in the second map. In the two first maps, a total of six isolated anomalies aligned parallel to the East wall of the convent can be identified (characterized by red and brown tonalities) having calculated electrical resistivity values that range between 23.4 and $50.0 \Omega$.m, although in the first horizontal map, some of these tend to be confused with the series of strong electrical anomalies found in the central part of the surveyed area. In turn, the third horizontal map only presents four of these electrical anomalies, situated in the central part of this alignment.

In the second horizontal map, another series of strong isolated anomalies is visualized between 33 and $35 \mathrm{~m}$ along the $x$ axis and extending along the $y$ axis; however these cannot be seen clearly in either the upper or the lower horizontal maps. In the upper map only one of these strong anomalies can be identified, which is situated at the western end of the convent. This anomaly is characterized by (red and brown tonalities) a range of calculated electrical resistivity values that vary between 23.4 and $50.0 \Omega$.m. This becomes more spatially extensive in the second map and less intense in the final horizontal map. Of this series, only three of these anomalies can be identified on the lower horizontal map.

Meanwhile, in the first two horizontal maps, an (red) electrical anomaly can be visualized that extends to the eastern end of the convent, with calculated electrical resistivity values that vary between 23.4 and $34.2 \Omega$.m. In the third horizontal map, the electrical anomaly becomes weak (shown in yellow). Finally, between positions 10 and $15 \mathrm{~m}$ along the $x$ axis and $10 \mathrm{~m}$ along the y axis an orange and red circular electrical anomaly with a diameter of approximately 3,5 m can be identified, whose electrical resistivity values range from 16.1 to $23.4 \Omega$.m. The same appears in the two final horizontal maps.

\section{Interpretation of the geophysical results and archeological exploration}

The interpretation of the horizontal maps in Figure 6 as a product of the $3 \mathrm{D}$ inversion of the apparent electrical resistivity data is shown in Figure 7. The series of anomalies that have high or intermediate calculated electrical resistivity values parallel to the north wall of the convent is limited by rectangle $\mathbf{A}$ in horizontal maps (a), (b) and (c) in Figure 7. According to the results of the archaeological interventions 


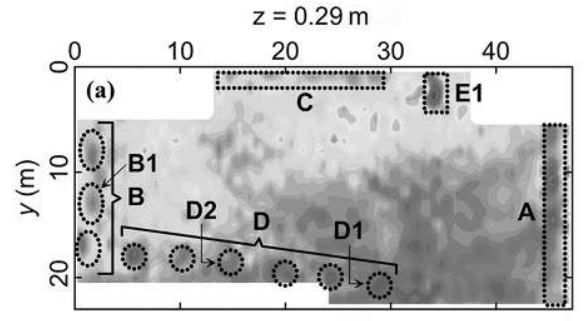

$z=1.60 m$

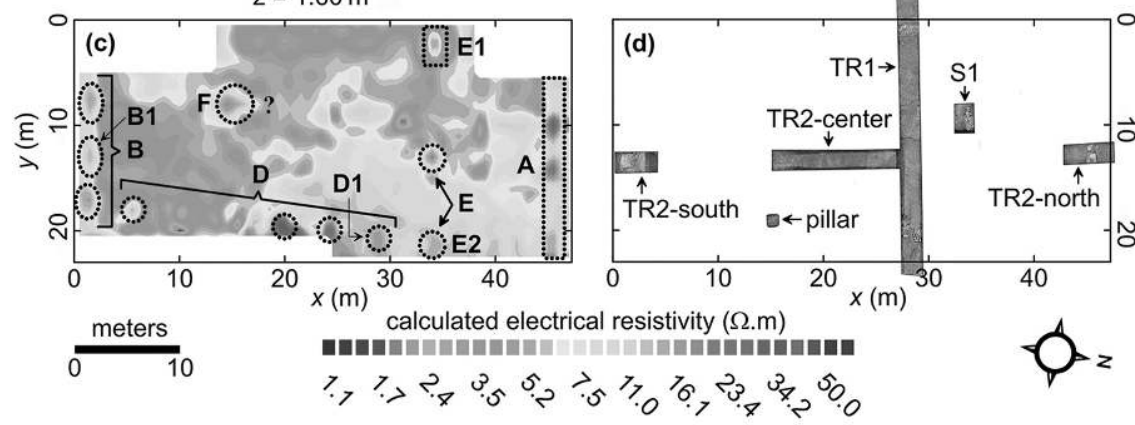

(a)

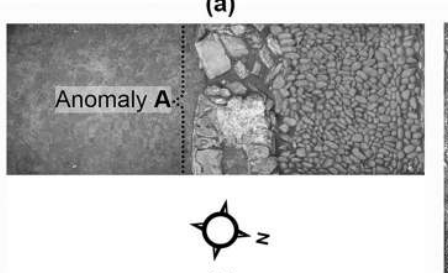

(b)

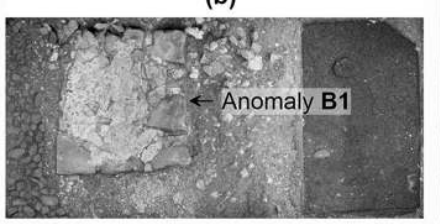

Figure 8: (See colour plate XX) Relationship between electrical anomalies and the results of the archaeological excavations (directed by M. Linero of the Patronato de Panamá Viejo) in: a) TR2-north, b) TR2-south, c) TR1west sector, d) TR1-east sector, e) the pillar and f) S1. Figure 8: (Voir planche couleur XX) Rapport entre les anomalies électriques et les résultats des fouilles archéologiques (dirigée par M. Linero du Patronato de Panamá Viejo) dans: a) TR2-nord, b) TR2-sud, c) TR1-secteur ouest, d) TR1-secteur est, e) le pilier et f) S1.

Figure 7: (See colour plate XX) Interpretation of the main electrical anomalies reflected in horizontal maps obtained at depths of a) $0,29 \mathrm{~m}$, b) $0,90 \mathrm{~m}$ and c) 1,60 m, and d) result of the excavations performed inside Santo Domingo Convent.

Figure 7: (Voir planche couleur XX) Interprétation des anomalies électriques principales dans les cartes horizontales aux profondeurs de a) 0,29 $\mathrm{m}, \mathrm{b}) 0,90 \mathrm{met}$ c) $1,60 \mathrm{~m}$, et d) résultats des fouilles effectuées à lintérieur du Couvent de Santo Domingo.

(c)

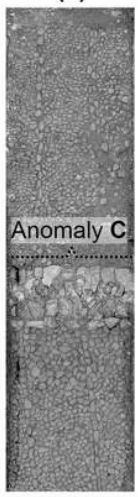

(d)

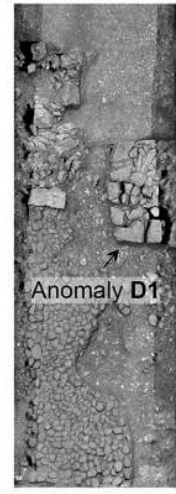

(e)

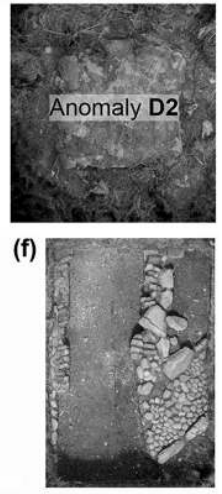

According to the excavation performed in the south trench (TR2-South in Figure 7d), that base formed part of the portico of the south gallery of the cloister. Figure $8 \mathrm{~b}$ ) presents the result of the archaeological excavation performed in this sector of the site, where the use of stones to build that base can be observed. This discovery suggests that the other isolated anomalies correspond to the series of pillar bases that make up this part of the cloister.

Meanwhile, the electrical resistivity anomaly with intermediate values and linear geometry that appears on the west side of the surveyed area is represented by the rectangle shown in dashed lines, or anomaly $\mathbf{C}$. According to the results of the archaeological excavations performed in the east-west trench (see Figure 7d called TR1), anomaly $\mathbf{C}$ is associated with a wall base that separates the western corridor of the cloister from the central patio, which is found to have been built using pebbles. This foundation is $1 \mathrm{~m}$ thick 
and is made of sandstone, which is a characteristic element of the site. Figure $8 \mathrm{c}$ shows a photograph of the western part of trench TR1.

By interpreting the results obtained in the east sector of the convent, the isolated anomalies revealed by the first two horizontal maps of calculated electrical resistivity (called series $\mathbf{D}$ ) approximately follow a parallel alignment to the east wall of the convent. Electrical anomaly D1 is found to be associated with the base of a pillar, according to the excavation performed in the eastern part of excavation TR1 (see Figure $7 \mathrm{~d}$ ); in this same context, the pillar that is visually identified in the southeastern part of the convent (Figures $7 d$ and $8 \mathrm{e}$ ) generates a clear isolated anomaly in the first two horizontal maps only; this indicates that there is no vertical or deep extension of the aforesaid structure that is greater than $1 \mathrm{~m}$; this is anomaly $\mathbf{D} 2$ identified in Figures $7 \mathrm{a}$ and b. This indicates that the other isolated electrical anomalies in series $\mathbf{D}$ could be associated with a series of pillar footings in the east gallery of the convent.

Anomaly E1, located at the eastern end of the convent, appears in the three horizontal maps (Figures $7 \mathrm{a}, \mathrm{b}$ and c) and could be associated with a highly superficial structure; this might be related somehow to series $\mathbf{E}$ of isolated anomalies that can be clearly identified in Figure 7b. This latter set of high calculated electrical resistivity features probably corresponds to the first stone foundations of the convent, dating back to its initial phase when it was known as the wooden house, as stated earlier. As for Anomaly E2, this could either be associated with the foundations of the primitive convent or with one of the pillar footings of a probable north gallery that would be never completed.

Meanwhile, the (red) electrical anomaly that extends across a large part of the central and north sector of the convent is found to be associated with an accumulation of tile fragments that were part of the convent's construction materials. This is possibly why it is hard to associate any one anomaly with any of the ends of the conduit system identified by sounding S1 (Figure 8f). Finally, the circular electrical feature that is observed in the southwest part of the convent and that is visible in the second and third horizontal maps of calculated electrical resistivity (Anomaly F) could be associated with the remains of the roots of an old tree.

It is important to stress that of the three horizontal maps obtained in this study. It is the second, at a depth of $0,90 \mathrm{~m}$, which produced the best results.

From the results obtained, a cloister surrounded by three galleries could be identified; one in the west, separated from the patio by an adjacent wall in the form of a sill and out of which the pillars projected; and those in the south and east. Formed by pillars exposed to light of approximately one lumen $(4,2 \mathrm{~m})$. To date, it is not clear whether the north gallery was actually built.

Meanwhile, the archaeological and historical evidence, from a study of the pieces of tile found in the archaeological excavations, confirm the existence of pillars in the cloister. A comparison of the tile pieces found in these excavations with the tile-based ornamental models from the cloister at Santo Domingo Convent, Lima (Peru) shows that they are the same (Arosemena and Durán, 2014). There is evidence that the tiles in the cloister at Santo Domingo, Lima were imported directly from potteries in Triana, Seville (Pita, 1991), which very possibly came from the Hernando de Valladares factory (Pleguezuelo, 2013).

From the use of such ornamentation in Lima to cover the cloister walls and pillars, it is inferred that the tiles were used in Panama in the same way as they were in Lima, as wall and pillar covering, thereby suggesting the existence of cloister pillars, the bases of which were identified in the geophysical and archaeological study.

\section{Conclusions}

The horizontal maps that show the spatial distribution of the calculated electrical resistivity values obtained from 3D inversion of the field data from Santo Domingo Convent have revealed a series of electrical anomalies linked to buried archaeological features, with characteristics in terms of size, form and depth that are typical of the period of Spanish colonization of the Americas. The vast majority of these anomalies with high and intermediate calculated electrical resistivity values have been interpreted as Hispanic structures associated with a typical cloister in convents of that period. The use of interpolation algorithms and representation of the contours of calculated electrical resistivity iso-values (at different depths) was the key factor for establishing a connection between the information obtained from electrical surveying and the results of the archaeological intervention performed at the convent, which permitted a better interpretation of the work done. Of the three horizontal maps obtained, the second provided the most information about the site. The electrical anomalies with high electrical resistivity values that presented a pattern of approximate alignment are associated with a series of stone pillars and footings that were used to support a second gallery, in accordance with the historic information about the building. Meanwhile, the electrical anomalies with linear geometries and calculated electrical resistivity values in the intermediate range are associated with walls that served as a boundary between the perimeter corridor of the cloister 
and one of the streets on the perimeter of the convent. The accumulation of materials from the period (tiles and ceramics) in the central part of the convent as a result of the structure collapsing generated an anomaly with intermediate electrical resistivity values. The circular anomaly with intermediate calculated electrical resistivity values situated in the southwest section of the convent and located in the second and third horizontal maps might be associated with the existence of an area of characteristic roots of a possible tree, which suggests the need for a future exploration of this part of the convent. The information found in the geophysical survey and archaeological excavations provides evidence of Hispanic richness in the Isthmus of Panama; this study has provided a better understanding of aspects of the historic evolution of the cloister and of Santo Domingo Convent in Panama, in particular due to the anomalies that were interpreted as probable footings of the convent in its initial wooden period, which should continue to be explored by means of archaeological excavation in order to corroborate this hypothesis. In parallel, geophysical survey with archeological excavations have helped to identify the probable layout of the pillars and galleries in the cloister that were linked to the most advanced phase of the convent, shortly before it was abandoned.

\section{Acknowledgements}

The authors would like to thank the National Secretariat for Science, Technology, and Innovation (SENACYT, Grant Number: FID11-096) for funding this archaeological rescue project. National Research System (SNI) of SENACYT for all the support. Milagros Pinto (Head of the Laboratorio de Investigación en Ingeniería y Ciencias Aplicadas) and Angela Laguna (Director of the Centro Experimental de Ingenieria), both from the Universidad Tecnologica de Panamá, for the support received to ensure the good development of the project; and finally Mirta Linero, Director of the Archaeology Department at the Patronato Panamá Viejo for providing information concerning the archaeological excavations conducted at the convent. The authors would like to thanks the reviewers for systematic review of the whole manuscript and their useful suggestions.

\section{Bibliography}

Arosemena G., Durán F., 2014. Informe de estudio interpretativo del claustro. Etapa II del Proyecto de recuperación arqueológica y paisajistica del claustro del Convento de Santo Domingo del Conjunto Monumental Histórico de Panamá Viejo. Report FID11-096, Panama.

Barker R., 2001. Principles of electrical imaging. Research Notes. University of Birmingham, United Kingdom.

Constable S.C., Parker R.L., Constable C.G., 1987. Occam's inversion - A practical algorithm for generating smooth models from electromagnetic sounding data. Geophysics, 52: 289-300.

DeGroot-Hedlin C., Constable S.C., 1990. Occam's inversion to generate smooth two-dimensional models from magnetotelluric data. Geophysics, 55: 1613-1624.

Dey A., Morrison H.F., 1979. Resistivity modeling for arbitrarily shaped three-dimensional structures. Geophysics, 44: 753-780.

Linero M., Muñíz J.R., 2015. Aportaciones arqueológicas al análisis del arte decorativo murario en Panamá durante el Siglo XVI: Azulejería sevillana del convento de Santo Domingo, Panamá Viejo. Canto Rodado, 10: 73-94.

Mena García M., 1992. La ciudad en un cruce de caminos: Panamá y sus orígenes urbanos. Publicaciones de la Escuela de Estudios Hispanoamericanos de Sevilla, Spain.

Minelli A., Cozzolino M., Di Nucci A., Guglielmi S., Giannantonio M., D’Amore D., Pittoni E., Groot A.M., 2012. The Prehistory of the Colombian Territory: the Results of the Italian Archaeological Investigation on the Checua Site (Municipality of Nemocón, Cundinamarca Department). Journal of Biological Research, 85: 94-97.

Osella A., de la Vega M., Lascano E., 2005. 3D electrical imaging of an archaeological site using electrical and electromagnetic methods. Geophysics, 70: G101-G107.

Pita M.T., 1991. Los predicadores novohispanos del siglo XVI. Editorial San Esteban, Salamanca, Spain.

Pleguezuelo A., 2013. Un palacio de azulejos. In Apuntes del Alcázar de Sevilla. Patronato del Real Alcázar y de la Casa Consistorial, Sevilla, Spain, 214-233.

Stewart R.H., Stewart J.L., Woodring W.P., 1980. Geologic map of the Panama Canal and vicinity, Republic of Panama. United States Geological Survey Miscellaneous Investigations Series Map I-1232, scale 1:100000.

Wake T., Mojica A., Davis M., Campbell C., Mendizábal T., 2012. Electrical Resistivity Surveying and Pseudo ThreeDimensional Tomographic Imaging at Sitio Drago, Bocas del Toro, Panama. Archaeological Prospection, 19: 49-58. 